\title{
Causal link between Quaternary paleoclimatic changes and volcanic islands evolution
}

\author{
X. Quidelleur, ${ }^{1}$ A. Hildenbrand, ${ }^{1}$ and A. Samper ${ }^{1}$ \\ Received 28 August 2007; revised 29 November 2007; accepted 6 December 2007; published 19 January 2008.
}

[1] Giant landslides and resulting tsunamis represent the main geologic hazards linked to volcanic island evolution. From offshore and onland studies, flank failures have been identified around numerous islands, in most geodynamic contexts. However, the triggering conditions are still poorly understood and several causes may act simultaneously to reach a critical threshold. Here we show that most large volume $\left(>10 \mathrm{~km}^{3}\right)$ landslides occur at glacial stages termination and we propose that a causal relationship between flank collapse of volcanic islands and global climatic changes has existed at least since $900 \mathrm{kyr}$. Moreover, ages reported here favour the hypothesis that major collapses occurred during the onset of glacial to interglacial transitions when sudden influx of melt water from polar ice caps causes rapid sea level rise. We propose that rapid sea level rise induces enhanced coastal erosion and sudden changes of pore pressure conditions within basal layers, which favour edifice failure. Citation: Quidelleur, X., A. Hildenbrand, and A. Samper (2008), Causal link between Quaternary paleoclimatic changes and volcanic islands evolution, Geophys. Res. Lett., 35, L02303, doi:10.1029/2007GL031849.

\section{Introduction}

[2] Catastrophic flank collapses events have been reported for numerous intra-plate oceanic islands, e.g. at Hawaii [Moore et al., 1994], Canary Islands [Carracedo et al., 1999; Masson et al., 2002; Watts and Masson, 1995], Tahiti [Clouard et al., 2001; Hildenbrand et al., 2004] and Cape Verde Islands [Day et al., 1999; Elsworth and Day, 1999], and around volcanic islands from oceanic arcs [Deplus et al., 2001; Kokelaar and Romagnoli, 1995; Satake and Kato, 2001]. Lateral collapses also affect volcanic edifices built on continental crust but usually with a volume far smaller than on oceanic volcanoes. In the present study, only large volume $\left(>10 \mathrm{~km}^{3}\right)$ landslides, all of them from volcanic islands, are considered. Several internal and external causes have been proposed as the main triggering condition [McGuire, 1996]. Volcanic rift zones have been recognized in many oceanic islands and have been linked to edifice failures [Siebert, 1984]. They concentrate magma upwelling as dyke swarms, which can trigger instability by strength reduction through thermal or mechanical pressurization of pore fluids [Elsworth and Day, 1999], or by the growth of an anomalously high topographic load [McGuire, 1996]. Slope angle and gravitational instability certainly favour failure, but low-angle edifices such as

\footnotetext{
${ }^{1}$ Laboratoire Interactions et Dynamique des Environnements de Surface, UMR 8148, CNRS, UPS, Université Paris Sud 11, Orsay, France.

Copyright 2008 by the American Geophysical Union. 0094-8276/08/2007GL031849
}

shield volcanoes are also prone to large flank destabilization. Asymmetric building onto a dipping basement can direct collapses towards a preferred direction. Such structural control of preferred landslide direction has been advocated in the Lesser Antilles [Deplus et al., 2001]. Caldera collapse events can also be associated with flank collapses, and has even been proposed as the main triggering factor for the formation of the Las Cañadas depression at Tenerife [Hürlimann et al., 1999]. However, the exact relationship between directed blast, caldera formation and flank failure remain difficult to establish [Siebert, 1984]. Instantaneous destabilization of weakened edifices can result from strong regional earthquakes, or from seismicity along listric basement faults acting as decollement surfaces. Reduction of strength of the basal volcanic layers by hydrothermal alteration and/or increased pore fluid pressure during high rainfall periods can also favour instability.

[3] A significant increase in explosive volcanism since the Early Miocene has been reported and was interpreted as a consequence of the rapidly changing climatic conditions which have characterized this interval [Kennett and Thunell, 1975]. This correlation has also been recognized for shorter time scales in the distribution of tephra layers within $\delta^{18} \mathrm{O}$ changes recorded in Greenland GISP2 ice core [Zielinski et al., 1996], and in the Mediterranean basin [McGuire et al., 1997], during the last $110 \mathrm{kyr}$.

[4] In order to investigate a possible relationship between global Quaternary climatic changes and catastrophic mass wasting affecting volcanic islands, high quality age determinations of these events are required. Two approaches are followed, but well dated events remain scarce.

[5] The first dating approach is based on $\delta^{18} \mathrm{O}$ stratigraphy from sediments located below and above landslide deposits, or directly on the deposits themselves [McMurtry et al., 1999], or on deposits carried by landslide-induced tsunamis [McMurtry et al., 2007].

[6] The second approach is based on radiometric dating, most often using the K/Ar Cassignol-Gillot technique [Gillot and Cornette, 1986], which is especially suitable to date accurately Quaternary volcanism up to the last millennium [Quidelleur et al., 2001]. This technique relies on severe sample selection followed by meticulous mineralogical separation of the fresh volcanic groundmass, which crystallizes last during sub-aerial cooling of the lava flows. Any concern related to excess (mantle derived) argon, or Ar or K loss during weathering is therefore avoided. Furthermore, this technique does not require artificial irradiation of the sample in a nuclear reactor. Hence, no ${ }^{39}$ Ar recoil occurs, and high isotopic interferences correction necessary with the ${ }^{40} \mathrm{Ar} /{ }^{39} \mathrm{Ar}$ technique for basalt and andesite samples is avoided. Accurate age determinations of flank failure are challenging because direct radiometric dating of these 
events is not feasible in most case, unless the collapse is associated with the emplacement of a pyroclastic blast, which can be dated only if its mineralogical content is favourable. Alternatively, the age of a landslide event can be bracketed by dating the last volcanic flows emplaced before the collapse, as well as the post-collapse magmatism. However, due to the lack of age data, only a few events are well constrained by both pre and post-collapse magmatism.

[7] Physical modeling and field studies have shown, however, that volcanoes collapse is generally immediately followed by renewed activity. This has been related to sudden pressure drop within the magma chamber subsequently to collapse deloading [Pinel and Jaupart, 2000]. At Tahiti, for instance, rapid in fill of the depression caused by a giant northern flank collapse occurred at a rate of $5 \mathrm{~km}^{3} / \mathrm{kyr}$, while the eruptive rate before the collapse was estimated to a maximum of $2 \mathrm{~km}^{3} / \mathrm{kyr}$ [Hildenbrand et al., 2004]. A causal link between collapse events and renewed activity has also been evidenced at Oahu (Hawaii), where mass wasting triggered volcanism is associated with increased partial melting [Presley et al., 1997]. The time interval between collapse and renewed volcanism is therefore very short. In the present study, we then rely only on the age of the volcanic edifice emplaced after the collapse.

\section{Ages of Well Constrained Flank Collapses}

[8] In the Canary archipelago large debris avalanches have been identified around the young volcanic islands of La Palma, El Hierro and Tenerife. At La Palma, the development of the $5 \mathrm{~km}$ wide erosion caldera de Taburiente has been linked with the Cumbre Nueva collapse of the northern shield, followed by the rapid emplacement of the Bejenado volcano within the collapse scar [Carracedo et al., 1999]. The associated debris avalanche deposits observed on the ocean floor to the west of the island cover an area of $780 \mathrm{~km}^{2}$, with an estimated volume of about $100 \mathrm{~km}^{3}$ [Masson et al., 2002]. The last construction stage of the northern shield on the rim of the Taburiente has been dated at $566 \pm 8 \mathrm{ka}$, while the earliest basal stage of the postcollapse Bejenado volcano is $537 \pm 8$ ka old [Guillou et al., 2001]. The later age is our best estimate for the Cumbre Nueva collapse. Several large-scale collapses have affected El Hierro, the westernmost Island of the archipelago [Carracedo et al., 1999; Gee et al., 2001; Masson, 1996; Masson et al., 2002; Mitchell et al., 2002]. The debris avalanche of El Golfo, with its clearly associated embayment onland, covers an area of $1500-2600 \mathrm{~km}^{2}$, for a volume of about $150-180 \mathrm{~km}^{3}$, while the volume and the extent of the underlying Tinor landslide are difficult to retrieve. Latter collapses of Las Playas and El Julan are not well dated enough, but the El Golfo event is better constrained, with a two stages landslide [Carracedo et al., 1999], the first at $134 \pm 6 \mathrm{ka}$ and the second at $15 \pm 2 \mathrm{ka}$, based on K-Ar dating of pre- and post collapse lavas, respectively [Guillou et al., 1996]. From the lack of strong evidences in the debris avalanche deposits offshore, the two stages hypothesis has been questioned [Masson et al., 2002]. However, on-land studies seem to argue for the two stages hypothesis [Carracedo et al., 1999], which is considered here (Table 1). On the island of Tenerife, several horse-shoe shaped valleys located across the NE rift zone have been related to major flank collapse events [Ablay and Hürlimann, 2000; Masson et al., 2002; Watts and Masson, 1995]. Orotava and Icod valleys are directed to the northwest and Guimar to the south east. Only the Icod landslide, the youngest of these events, is sufficiently well dated. Its offshore deposits extend to $1700 \mathrm{~km}^{2}$ with a volume of $150 \mathrm{~km}^{3}$. The Teide volcano emplaced subsequently to the landslide, on top of the resulting "Mortalon" breccia. Dating of the lowermost lava flow of the Teide, sampled within a water-recovery gallery at the contact with the landslide breccia, constrained the Icod landslide at $161 \pm$ $5 \mathrm{ka}$ [Gillot et al., 2001]. This age is in good agreement with the ${ }^{40} \mathrm{Ar}{ }^{39} \mathrm{Ar}$ ages of $163 \pm 1$ ka [van den Bogaard and Schirnick, 2001] and $169 \pm 1 \mathrm{ka}$ [Brown et al., 2003] obtained from sanidine separates from the plinian eruption of El Abrigo, which has been related to the Icod landslide. However, note the discrepancy between the two latter ages at the $1 \sigma$ level, which we attribute to underestimated uncertainties.

[9] Offshore bathymetry measurements have demonstrated that recurrent mass wasting events have affected most islands from the Lesser Antilles volcanic arc within the last 200-100 kyr, with associated volumes of about 30 and $20 \mathrm{~km}^{3}$ reported off southern Dominica and Montagne Pelée (Martinique), respectively [Deplus et al., 2001]. Due to the relatively high sedimentation rate within the Grenada basin, older collapse events cannot be identified offshore, but on-land morphological studies coupled with precise $\mathrm{K} / \mathrm{Ar}$ age determinations allowed the identification and dating of two major events on Guadeloupe and Martinique Islands. An age of $659 \pm 11 \mathrm{ka}$ was obtained for the last construction phase of the pre-collapse Matéliane volcano (Guadeloupe Island), and a younger age of $629 \pm 13 \mathrm{ka}$, which therefore dates the collapse, was obtained for the Icaques volcano emplaced subsequently within the landslide depression [Samper et al., 2007]. Large debris avalanche deposits found on-land within a large horseshoe-shaped depression demonstrated that a major flank collapse event, with a volume estimated around $30-40 \mathrm{~km}^{3}$, occurred on Martinique, and was followed by the rapid emplacement of the Pitons du Carbet at $337 \pm 5 \mathrm{ka}$ [Quidelleur et al., 2004], which represents the best age estimate for this collapse.

[10] Catastrophic mass wasting events have been imaged around all the islands of the Hawaiian archipelago. Submarine areas covered by the deposits typically range from 2,000 to $15,000 \mathrm{~km}^{2}$, and estimated volumes amount to $5000 \mathrm{~km}^{3}$ [Moore et al., 1994]. As many as 68 major landslides were reported along the Hawaiian stretch, from Midway to the island of Hawaii, with an average rate of one major landslide every $350 \mathrm{kyr}$ [Moore et al., 1994], estimate recently revised to a much shorter recurrence time [Garcia et al., 2006]. Unfortunately, only the Alika phase 2 collapse from the Mauna Loa volcano (Big Island) is well dated with an age of $127 \pm 5$ ka derived from the correlation between high $\delta^{18} \mathrm{O}$ values measured from planktonic foraminiferal assemblages, sampled within turbidite deposits, and the global reference curves [McMurtry et al., 1999]. Unfortunately, probably because of the low $\mathrm{K}$ content of shield building tholeitic basalts, none of the Hawaiian collapses is accurately dated by the K-Ar method. 
Table 1. Well-Dated Oceanic Island Collapses With Volume Larger Than $10 \mathrm{~km}^{3 \mathrm{a}}$

\begin{tabular}{llclll}
\hline Location & Collapse & Volume, $\mathrm{km}^{3}$ & Age, ka & Dating Method & Reference \\
\hline La Palma & Cumbre Nueva & $100-200$ & $537 \pm 8$ & $\mathrm{~K} /$ Ar post-col. & [Guillou et al., 2001] \\
El Hierro & El Golfo 1 & $150-180$ & $134 \pm 6$ & $\mathrm{~K} /$ Ar pre-col. & [Carracedo et al., 1999] \\
& El Golfo 2 & $250-350$ & $15 \pm 2$ & K/Ar post-col. & [Masson, 1996] \\
Tenerife & Icod & 150 & $161 \pm 5$ & K/Ar post-col. & [Gillot et al., 2001] \\
Guadeloupe & Icaques & $10-20$ & $629 \pm 13$ & K/Ar post-col. & [Samper et al., 2007] \\
Martinique & Carbets & $30-40$ & $337 \pm 5$ & K/Ar post-col. & [Quidelleur et al., 2004] \\
Hawaii & Alika 2 & $200-800$ & $127 \pm 5$ & $\delta^{18}$ O strat. & [McMurtry et al., 1999] \\
Tahiti & North & $400-450$ & $872 \pm 10$ & K/Ar post-col. & [Hildenbrand et al., 2004] \\
\hline
\end{tabular}

${ }^{a}$ Age is given with an analytical uncertainty of 1 sigma. $\mathrm{K} / \mathrm{Ar}$ pre-col. and $\mathrm{K} / \mathrm{Ar}$ post-col.: age derived from $\mathrm{K} / \mathrm{Ar}$ dating of pre-, or post-collapse, volcanism, respectively. $\delta^{18} \mathrm{O}$ strat.: age derived from oxygen isotopes stratigraphy.

[11] Following the construction of a first shield volcano, between $1.37 \pm 0.02 \mathrm{Ma}$ and $0.87 \pm 0.02 \mathrm{Ma}$ [Hildenbrand et al., 2004], Tahiti Island (French Polynesia) experienced two major flank collapses directed south and north, respectively. The former, identified offshore, has an estimated volume of $300 \mathrm{~km}^{3}$ onshore with a total debris volume of $1150 \mathrm{~km}^{3}$ [Clouard et al., 2001]. The latter left an on-land depression volume of $400-450 \mathrm{~km}^{3}$ and offshore debris volume of about $800 \mathrm{~km}^{3}$ [Hildenbrand et al., 2006]. Both landslides have been related to the E-W rift zone developed during the subaerial growth of the main shield. The subsequent emplacement of the second shield volcano within the northern collapse depression started at $872 \pm$ $10 \mathrm{ka}$ [Hildenbrand et al., 2004], which then can be used as the accurate dating of the northern collapse (Table 1).

\section{Discussion}

[12] All major flank collapses affecting volcanic islands with well-constrained timing control, most often obtained using the K-Ar Cassignol Gillot technique [Gillot and Cornette, 1986], are reported in Table 1. Figure 1 shows the correlation of these events with Quaternary climate changes as described by a global stack of benthic $\delta^{18} \mathrm{O}$ records [Lisiecki and Raymo, 2005]. It is striking to note that most collapses occurred within a glacial to interglacial transition, which does not exceed $15 \mathrm{kyr}$ [e.g., Lambeck et al., 2002]. As previously suggested for the onset of interglacial stage 5.5 (about $125 \mathrm{ka}$ ) [Carracedo et al., 1999; McMurtry et al., 1999], we show here that a direct link between climatic change and long-term evolution of oceanic volcanoes prevailed during the last $900 \mathrm{kyr}$ (Figure 1).

[13] To a first order, $\delta^{18} \mathrm{O}$ variations can be considered as a good proxy for sea level changes resulting from glacialinterglacial cycles, with an inverse relationship between $\delta^{18} \mathrm{O}$ values and relative sea level [Lambeck et al., 2002]. Low $\delta^{18} \mathrm{O}$ values indicate small ice volume and hence warm global climatic conditions, and, alternatively, high $\delta^{18} \mathrm{O}$ values indicate large continental ice volume and hence cold global climatic conditions. In order to further identify the causal link between climate change and volcanic collapse, it is necessary to discriminate if volcanic collapses occur during high sea level intervals, and are thus favoured by hot and humid climatic conditions, or, alternatively, if they occur during drier climate under low sea level stand. Figure 1 shows that most events are rather located towards the onset of the rapid climatic changes, except Tenerife collapse, which occurred during a secondary minimum of a glacial interval. Within uncertainty, they all include the coldest intervals (high value of $\delta^{18} \mathrm{O}$, i.e. minima in Figure 1). In addition, since the dating approach followed here is mainly based on the age of the post-collapse volcanic emplacement, the age of the collapse itself can only be biased towards younger ages and the ages reported here (Table 1 and Figure 1) must be considered as strict younger bounds.

[14] The youngest collapse of El Hierro (Table 1) has been related with a volcanoclastic turbidite emplaced on the Madeira abyssal plain during the last deglaciation, between oxygen isotopic stages 2 and 1 [Masson, 1996]. Similarly, the intermediate values of $\delta^{18} \mathrm{O}$ recorded within the associated turbidite [McMurtry et al., 1999] show that the Alika 2
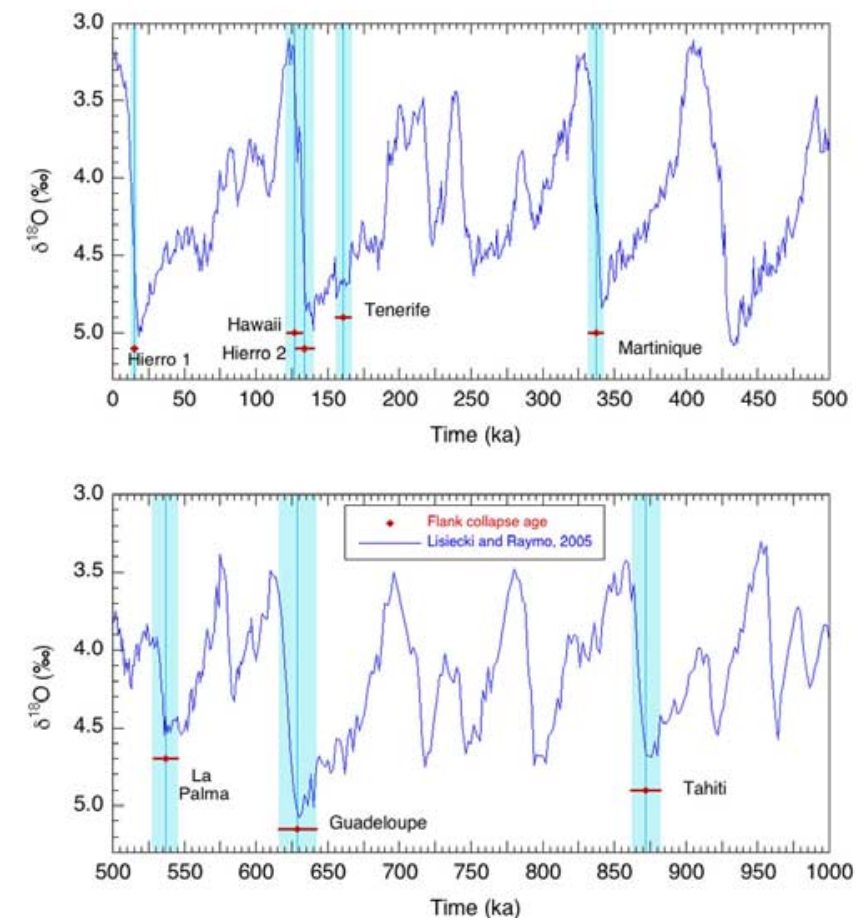

Figure 1. Ages of well-dated oceanic island flank collapses (red diamond) compared with Quaternary climatic changes as shown by a stack of 57 globally distributed $\delta^{18} \mathrm{O}$ records [Lisiecki and Raymo, 2005] (deep blue continuous curve), for the $0-500$ and 500-1000 ka intervals. Analytical age uncertainties $(1 \sigma)$ are shown with light blue areas. 
giant landslide occurred during the fast glacial-interglacial climatic change, between isotopic stages 6 and 5 .

[15] All the above lines of evidence allow us to propose a model in which large scale flank collapses of volcanic islands occurred during rapid sea-level rise associated with deglaciation. However, this is not exclusive and collapses, although with a much smaller volume than those reported here (Table 1), have occurred within the last interglacial stage, at Stromboli [Gillot and Keller, 1993; Kokelaar and Romagnoli, 1995], Montagne Pelée in Martinique [Le Friant et al., 2003], or Enclos Fouquet at La Réunion [Gillot et al., 1994], for instance. Furthermore, flank collapses involving a few $\mathrm{km}^{3}$ of material took place during the historic period in Japan (Oshima-Oshima island [Satake and Kato, 2001]) and in New Guinea (Ritter island [Ward and Day, 2003]), in 1741 and 1888 A.D., respectively. These events can be interpreted as delayed collapses of weakened edifices, but are, in any case, one or several order of magnitude less voluminous than those investigated here (Table 1).

[16] Our hypothesis is apparently in contradiction to the suggestion that large failures are related to increased retention of groundwater during wet and warm climates characterizing interglacial periods [McMurtry et al., 2004]. However, the detailed patterns of sea level rise and rainfall at the transition between glacial to interglacial at tropical latitude needs further investigations.

[17] Paleo-sea level determinations, inferred from the direct dating of Barbados corals by U-Th, showed that the last deglaciation occurred with several surges in melt water [Bard et al., 1990]. Moreover, rapid flux of fresh water over 100 to 500 years through partial collapse of ice sheets has been reported at the onset of the deglaciation, around $19 \mathrm{ka}$ [Clark et al., 2004]. One can suppose that at the end of glacial periods, when the ice sheet growth is high, the onset of the deglaciation process and the subsequent rapid sea level rise affects the stability of volcanic edifices and can trigger large flank collapses, such as those reported here for the last $900 \mathrm{kyr}$.

[18] Several mechanisms can be proposed. During the low sea level stands, the equilibrium level of volcanic island rivers is lowered, producing an important vertical deepening of erosion canyons, which significantly alters the edifice stability. Then, when sea level rapidly rises, marine coastal erosion is strongly enhanced [Hapke and Green, 2006] and can destabilize the weakened volcanic edifice. In a similar fashion, it can also be proposed that the rapid sea level rise strongly changes the pore pressure conditions of porous layers such as soils and/or pyroclastic deposits, which were subaerial during low sea level stages and then previously dried due to a lowered basal water table. Such surfaces would act as the main decollement layers where the collapse initiates during rapid sea level rise.

\section{Conclusions}

[19] Large volume $\left(>10 \mathrm{~km}^{3}\right)$ flank failures have been identified in several volcanic islands distributed worldwide, but direct dating of these events remains rarely available. We present here the compilation of all available ages that constrain the timing of these events. Most of them were acquired using the unspiked Cassignol-Gillot $\mathrm{K}-\mathrm{Ar}$ radio- metric method with analytical uncertainty of about $1-2 \%$. Our approach is mainly based on dating of renewed magmatism emplaced subsequently to collapse, within the scare, and therefore represents a younger bound for the timing of collapse events. The comparison between these ages and sea level changes allow us to propose a causal link between flank collapse of volcanic islands from various geodynamic contexts and global climatic changes during late Quaternary (i.e. during the last $900 \mathrm{kyr}$ ). Effectively, most collapses occurred within a glacial to interglacial termination. Moreover, we propose that major flank collapse events took place at the older bounds of these intervals, during the onset of glacial to interglacial transitions, when sudden influx of melt water from polar ice caps causes rapid sea level rise. However, our conclusions, based on a still limited database, need to be reinforced by additional ages of flank collapse, when they will become available. Finally, this study highlights the need for high precision ages from Quaternary volcanic edifices to infer any mutual influences of global changes and volcanic eruptions.

[20] Acknowledgments. Reviews by G.M. McMurtry and an anonymous reviewer helped us to improve the clarity of this manuscript. This is LGMT contribution number 67.

\section{References}

Ablay, G., and M. Hürlimann (2000), Evolution of the north flank of Tenerife by recurrent giant landslides, J. Volcanol. Geotherm. Res., 103, 135-159.

Bard, E., B. Hamelin, and R. G. Fairbanks (1990), U-Th ages obtained by mass spectrometry in corals from Barbados: Sea level during the past 130,000 years, Nature, 346, 456-458.

Brown, R. J., T. L. Barry, M. J. Branney, M. S. Pringle, and S. E. Bryan (2003), The Quaternary pyroclastic succession of southeast Tenerife, Canary Islands: Explosive eruptions, related caldera subsidence, and sector collapse, Geol. Mag., 140(3), 265-288.

Carracedo, J. C., S. J. Day, H. Guillou, and F. J. P. Torrado (1999), Giant Quaternary landslides in the evolution of La Palma and El Hierro, Canary Islands, J. Volcanol. Geotherm. Res., 94, 169-190.

Clark, P. U., A. M. McCabe, A. C. Mix, and A. J. Weaver (2004), Rapid rise of sea level 19,000 years ago and its global implications, Science, $304,1141-1144$.

Clouard, V., A. Bonneville, and P. Y. Gillot (2001), A giant landslide on the southern flank of Tahiti Island, French Polynesia, Geophys. Res. Lett., 28, $2253-2256$

Day, S. J., S. I. N. Heleno da Silva, and J. F. B. D. Fonseca (1999), A past giant lateral collapse and present-day flank instability of Fogo, Cape Verde Islands, J. Volcanol. Geotherm. Res., 94, 191-218.

Deplus, C., A. Le Friant, G. Boudon, J.-C. Komorowski, B. Villemant, C. Harford, J. Ségoufin, and J.-L. Cheminée (2001), Submarine evidence for large-scale debris avalanches in the Lesser Antilles Arc, Earth Planet. Sci. Lett., 192, 145-157.

Elsworth, D., and S. J. Day (1999), Flank collapse triggered by intrusion: The Canarian and Cape Verde Archipelagoes, J. Volcanol. Geotherm. Res., 94, 323-340.

Garcia, M. O., S. B. Sherman, G. F. Moore, R. Goll, I. Popova-Goll, J. H. Nathland, and G. Acton (2006), Frequent landslides from Ko'olau volcano: Results from ODP hole 1223A, J. Volcanol. Geotherm. Res., 151, $251-268$.

Gee, M. J. R., A. B. Watts, D. G. Masson, and N. C. Mitchell (2001), Landslides and the evolution of El Hierro in the Canary Islands, Mar. Geol., 177(3-4), 271-293.

Gillot, P.-Y., and Y. Cornette (1986), The Cassignol technique for potassium-argon dating, precision and accuracy: Examples from late Pleistocene to recent volcanics from southern Italy, Chem. Geol., 59, 205-222.

Gillot, P.-Y., and J. Keller (1993), Radiochronological dating of Stromboli, Acta Vulcanol., 3, 69-77.

Gillot, P.-Y., J.-C. Lefèvre, and P.-E. Nativel (1994), Model for the structural evolution of the volcanoes of Réunion Island, Earth Planet. Sci. Lett., 122, 291-302.

Gillot, P. Y., V. Soler, and X. Quidelleur (2001), Piling rate and magmatic evolution through time of the Teide volcano (Tenerife, Canary islands), 
paper presented at XI Meeting, Eur. Union of Geosci., Strasbourg, France, 8-12 Apr.

Guillou, H., J. C. Carracedo, F. J. P. Torrado, and E. R. Badiola (1996), $\mathrm{K}-\mathrm{Ar}$ ages and magnetic stratigraphy of a hotspot-induced, fast grown oceanic island: El Hierro, Canary Islands, J. Volcanol. Geotherm. Res., $73,141-155$.

Guillou, H., J. C. Carracedo, and R. A. Duncan (2001), K-Ar, 40Ar/39Ar ages and magnetostratigraphy of Brunhes and Matuyama lava sequences from La Palma Island, J. Volcanol. Geotherm. Res., 106, 175-194.

Hapke, C. J., and K. R. Green (2006), Coastal landslide material loss rates associated with severe climatic events, Geology, 34, 1077-1080.

Hildenbrand, A., P.-Y. Gillot, and I. Le Roy (2004), Volcano-tectonic and geochemical evolution of an oceanic intra-plate volcano: Tahiti-Nui (French Polynesia), Earth Planet. Sci. Lett., 217, 349-365.

Hildenbrand, A., P.-Y. Gillot, and A. Bonneville (2006), Offshore evidence for a huge landslide of the northern flank of Tahiti-Nui (French Polynesia), Geochem. Geophys. Geosyst., 7, Q03006, doi:10.1029/ 2005 GC001003.

Hürlimann, M., E. Turon, and J. Martì (1999), Large landslides triggered by caldera collapse events in Tenerife, Canary Islands, Phys. Chem. Earth 24, $921-924$.

Kennett, J. P., and R. C. Thunell (1975), Global increase in Quaternary explosive volcanism, Science, 187, 497-503.

Kokelaar, P., and C. Romagnoli (1995), Sector collapse, sedimentation and clast population evolution at an active island-arc volcano: Stromboli, Italy, Bull. Volcanol., 57, 240-262.

Lambeck, K., T. M. Esat, and E.-K. Potter (2002), Links between climate and sea levels for the past three million years, Nature, 419, 199-206.

Le Friant, A., G. Boudon, C. Deplus, and B. Villemant (2003), Large-scale flank collapse events during the activity of Montagne Pelée, Martinique, Lesser Antilles, J. Geophys. Res., 108(B1), 2055, doi:10.1029/ 2001JB001624.

Lisiecki, L. E., and M. E. Raymo (2005), A Pliocene-Pleistocene stack of 57 globally distributed benthic $\delta^{18} \mathrm{O}$ records, Paleoceanography, 20, PA1003, doi:10.1029/2004PA001071.

Masson, D. G. (1996), Catastrophic collapse of the volcanic island of Hierro $15 \mathrm{ka}$ ago and the history of landslides in the Canary Islands, Geology, 24, 231-234.

Masson, D. G., A. B. Watts, M. J. R. Gee, R. Urgeles, N. C. Mitchell, T. P. Le Bas, and M. Canals (2002), Slope failures on the flanks of the western Canary Islands, Earth Sci. Rev., 57, 1-35.

McGuire, W. J. (1996), Volcano instability: A review of contemporary themes, in Volcano Instability on Earth and Other Planets, edited by W. J. McGuire, W. J. Jones, and A. P. Neuberg, pp. 1-23, Geol. Soc., London.

McGuire, W. J., R. J. Howarth, C. R. Firth, A. R. Solow, A. D. Pullens, S. J. Saunders, I. S. Stewart, and C. Vita-Finzi (1997), Correlation between rate of sea-level change and frequency of explosive volcanism in the Mediterranean, Nature, 389, 473-476.

McMurtry, G. M., E. Herrero-Bervera, M. D. Cremer, J. R. Smith, C. Sherman, and M. E. Torresan (1999), Stratigraphic constraints on the timing and emplacement of the Alika 2 giant Hawaiian submarine landslide, J. Volcanol. Geotherm. Res., 94, 35-58.
McMurtry, G. M., P. Watts, G. J. Fryer, J. R. Smith, and F. Imamura (2004), Giant landslides, mega-tsunamis, and paleao-sea level in the Hawaiian Islands, Mar. Geol., 203, 219-233.

McMurtry, G. M., D. R. Tappin, P. N. Sedwick, I. Wilkinson, J. Fietzke, and B. Sellwood (2007), Elevated marine deposits in Bermuda record a late Quaternary megatsunami, Sediment. Geol., 200, 155-165.

Mitchell, N. C., D. G. Masson, A. B. Watts, M. J. R. Gee, and R. Urgeles (2002), The morphology of the submarine flanks of volcanic ocean islands: A comparative study of the Canary and Hawaiian hotspot islands, J. Volcanol. Geotherm. Res., 115, 83-107.

Moore, J. G., W. R. Normark, and R. T. Holcomb (1994), Giant Hawaiian landslides, Annu. Rev. Earth Planet. Sci., 22, 119-144.

Pinel, V., and C. Jaupart (2000), The effect of edifice load on magma ascent beneath a volcano, Philos. Trans. R. Soc. London, Ser. A, 358, $1515-$ 1532.

Presley, T. K., J. M. Sinton, and M. Pringle (1997), Postshield volcanism and catastrophic mass wasting of the Waianae volcano, Oahu, Hawaii, Bull. Volcanol., 58, 597-616.

Quidelleur, X., P. Y. Gillot, V. Soler, and J. C. Lefèvre (2001), K/Ar dating extended into the last millennium: Application to the youngest effusive episode of the Teide volcano (Spain), Geophys. Res. Lett., 28, $3067-$ 3070 .

Quidelleur, X., A. Samper, G. Boudon, A. Le Friant, and J. C. Komorowski (2004), Radiometric dating of large volume flank collapses in the Lesser Antilles Arc., Eos Trans. AGU, 85(47), Fall Meet. Suppl., Abstract V41B-1397.

Samper, A., X. Quidelleur, P. Lahitte, and D. Mollex (2007), Timing of effusive volcanism and collapse events within an oceanic arc island: Basse Terre, Guadeloupe archipelago (Lesser Antilles Arc), Earth Planet. Sci. Lett., 258, 175-191.

Satake, K., and Y. Kato (2001), The 1741 Oshima-Oshima eruption: Extent and volume of submarine debris avalanche, Geophys. Res. Lett., 28, $427-430$.

Siebert, L. (1984), Large volcanic debris avalanches: Characteristics of source areas, deposits, and associated eruptions, J. Volcanol. Geotherm. Res., 22, 163-197.

van den Bogaard, P., and C. Schirnick (2001), The Diego Hernandez crisis: $40 \mathrm{Ar} / 39 \mathrm{Ar}$ dating of the youngest highly explosive eruption cycle on Tenerife, paper presented at 26th Assembly, Eur. Geophys. Soc., Nice, France, $21-26$ Apr

Ward, S. N., and S. Day (2003), Ritter Island Volcano-lateral collapse and the tsunami of 1888, Geophys. J. Int., 154, 891-902.

Watts, A. B., and D. G. Masson (1995), A giant landslide on the north flank of Tenerife, Canary Islands, J. Geophys. Res., 100, 24,487-24,498.

Zielinski, G. A., P. A. Mayewski, L. D. Meeker, S. Whitlow, and M. S. Twickler (1996), A 110,000-yr record of explosive volcanism from the GISP2(Greenland) ice core, Quat. Res., 45, 109-118.

A. Hildenbrand, X. Quidelleur, and A. Samper, Laboratoire Interactions et Dynamique des Environnements de Surface, UMR 8148 CNRS-UPS, Université Paris Sud 11, Bâtiment 504, F-91405 Orsay cedex, France. (xavier.quidelleur@u-psud.fr) 